\title{
Gender Differences In Resilience, Coping And Quality Of Life Of Oncology Nurses In Pakistan
}

\author{
Sajida Naz \\ Department of Behavioral Sciences \\ Fatima Jinnah Women University \\ Naima Saeed \\ Department, Criminology \\ University of Karachi \\ Aazadi Fateh Muhammad \\ Department of Mass Communication \\ Federal Urdu University for Arts, Science \& Technology
}

\begin{abstract}
This research was carried out to explore the gender differences in resilience, coping and quality of life of oncology nurses. It is evidenced through the literature that oncology nurses face different stressors because of complexity involved in their profession. This research attempts to investigate the impact of resilience and coping strategies on quality of life of nurses along with identifying nature of gender differences in each domain. A total of 300 oncology nurses (150 males and 150 females) participated in cross sectional survey based study. Trait and State Resilience Checklist, Brief Cope Scale and WHO Quality of Life scale were used to assess resilience, coping strategies and quality of life respectively. Results indicated significant gender differences in terms of coping strategies and quality of life. Moreover, resilience came out to be a strong predictor of quality of life in nurses. Findings of the study are discussed in terms of policy towards nursing stress management and coping intervention.
\end{abstract}

Keywords: Oncology Nurses, Stress, Resilience, Coping, Quality of Life, Gender Differences.

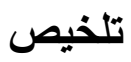

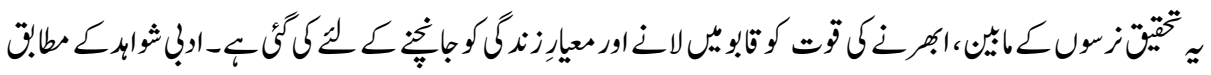

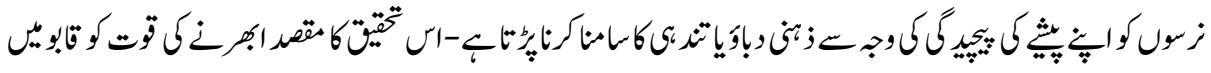

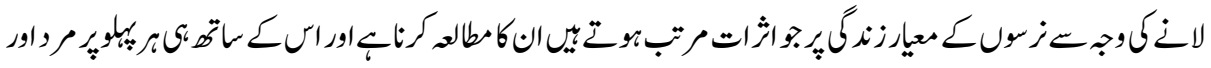

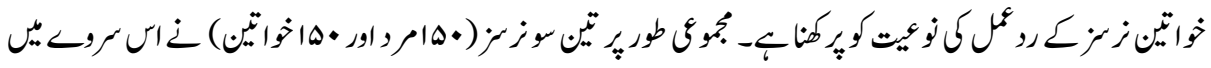

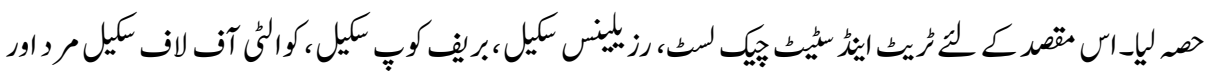

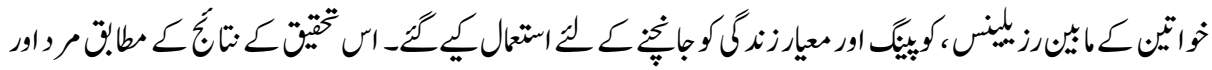




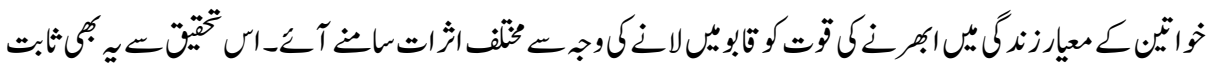

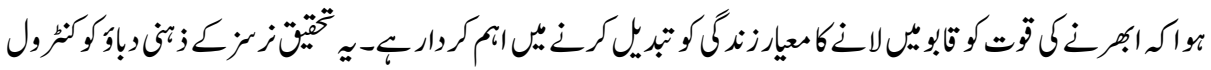

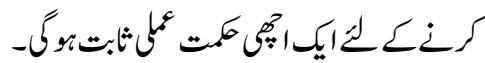

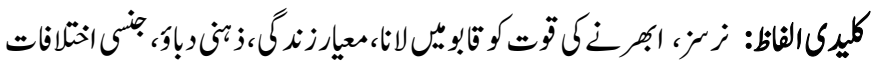

\section{Introduction}

In changing time, focus of health care provision has shifted from treating disease to managing and preventing illness for general population. For this reason, role of nurse in health care is of immense importance (Naylor \& Kurtzman, 2010). Over period of time, quality assurance demands and professional standards of nursing have increased levels of stress among nurses, and particularly those serving in emergency departments and intensive care units (Pedersen \& Hack, 2010). In Pakistan, nursing has been dominated by females, however the proportion of males has increased over past five years due to change in demand of social work and difficulty finding jobs for younger generation (Shahzad, \& Malik, 2014; Lee \& Saeed, 2001).

Male nurses are different from female counterparts in terms of taking and responding to stress (Grant, McMullen, Altschuler, Mohler, Hornbrook, Herrinton, \& Krouse, 2011). They may respond differently to stress at work through resiliency and develop coping strategies and therefore implications on quality of life may be attributed to these variables. This study therefore is conducted to identify gender differences in terms of resilience, coping and quality of life among male and female nurses.

Resilience refers to capacity to adapt successfully in midst of a challenging situation (Meichenbaum, 2007). It is a vital attribute in terms of nursing as it is required in their everyday work (Hart, Brannan \& De Chesnay, 2014). Research indicates gender differences in terms of resilience however specification about which gender is more resilient remains unexplained in nursing context. Different researches has been done within those groups of health professions in which the health providers are highly exposed to traumatic events such as nurses working in emergency units, ambulance and paramedical personnel. In these professions some characteristics e.g., openness, extroversion and agreeableness influence the posttraumatic growth (Shakespeare-Finch, Smith, \& Gow, 2005).

Several studies have been done in order to investigate the effect of age and gender on the resilience ability of an individual. Research suggests that self-esteem and age increases the resilience factors in individuals (Frost \& McKelvie, 2004). Resilience has been considered as the individual's characteristic to cope with adverse life circumstances (Luthar, 2006). Hampel \& Peterman (2005) has divided the coping into two types, maladaptive and adaptive strategies). Young people tend to use adaptive coping strategies 
which includes distraction, positive self-instruction, and direct action (Hampel \& Petermann, 2005; Hampel \& Petermann, 2006). Some researchers have shown that women score higher in empathy, help seeking behaviour and in communication with adults and peers (Broderick \& Korteland, 2002; Frydenberg \& Lewis, 1993; Hampel \& Petermann, 2005). Women show more pro-social behaviour (Heyman \& Legare 2004). The pattern of developmental style in resilience factors in male and females are different. The males are individual oriented and use problem solving strategies while females are relationship oriented and social (Heyman \& Legare 2004).

Another factor related to responding to stress is coping. The literature suggests that there exist gender differences in nurses in terms of coping strategies used by them. Golestan, Sayehmiri and Peyman (2011) investigated gender differences in coping strategies used by 158 nurses with equal proportion of male and female. The results showed significant association between the workplace and the gender and the coping strategies used by them. There is gender variation in terms of coping strategies. Several researches over period of time have suggested that men scored higher in instrumental support and female scored higher in emotional support coping strategy (Billings \&Moos, 1984; Endler \& Parker, 1990; Folkman \& Lazarus, 1980; Ptacek, Smith, \& Dodge, 1994). Several researchers also reported the similar findings where women use more emotional support coping styles than males in community groups (Billings \& Moos, 1981; Pearlin \& Schooler, 1978).

Third factor which contributes to effective stressful response in nursing profession is quality of life. Quality of life is subjective as well as objective dimension (Constantinescu, 2012; Isik \& Meriç, 2010). It is diverse and covers a broad range of domains of life. It includes conditions of health, opportunities of recreation, learning status, workplace environment and professional development. It has positive outcome for patients as well as nurses. Several researches have reported poor quality of life in male and female nurses attributing reasons to work pressure and poor physical health (Jafari, Sadegi, Batebi, Hosseini, Ebrahimpoor, Shojaei \& Vaezi, 2012).

The preponderance of literature suggests that there are gender differences in terms of resilience, coping and quality of life however gender differentiation is ambiguous with reference to nursing profession. Keeping in view the gaps in the literature, this study is carried out to find out if there are any gender differences in resilience, coping and quality of life of oncology nurses. It also examines impact of resilience and coping on quality of life in nurses.

\section{Method}

\section{Sample}

The sample consisted of 300 nurses working in oncology department of selected hospitals from Rawalpindi and Abbottabad using convenient sampling. Age of respondents varied from 22 to 50 years. Equal percentage of gender was ensured (i.e., $50 \%$ males and females). 


\section{Instruments}

A demographic sheet comprising of information related to gender, age, education, marital status, service duration was administered along with following list of measures of resilience, coping and quality of life respectively:

\section{State and Trait Resilience Checklist (Urdu version)}

State and resilience checklist was originally developed by Hiew (2000) Original State-Trait resilience inventory is adapted and translated to tackle cultural differences by Sarwar (2005), comprising of 2 subscales i.e., The State Resilience Checklist which has 15 items and Trait Resilience Checklist which comprises of 18 items. All items are arranged on five type Likert scale from strongly agree to strongly disagree. score is 75 and 90 for each subscale.

2. WHO Quality of Life Scale (Urdu version)

WHOQOL scale was originally developed by WHO and it was translated into urdu in 2003 by Khan, Akhtar, Ayub, Alam and Laghari. It is a subset of 26 items which is taken from WHOQOL-100. The scale has five domains namely: Physical QoL, Environmental QoL, Psychological QoL and Social QoL. Higher score in each domain represents higher quality of life in that domain as they are scaled in positive direction.

\section{Brief Cope Scale (Urdu version)}

Coping strategies used by the oncology nurses was measured by means of brief COPE scale. It was developed by Carver (1997). The Brief COPE scale was translated into Urdu by Akhtar (2005). The Brief COPE scale is the brief form of Coping Inventory. It consists of 28 items. The scoring is on four point Likert scale $(1=$ Never, $2=$ Very less, $3=$ Sometimes, $4=$ Not $)$. Brief COPE scale comprises of 14 Sub scales, comprised of 14 items each. These 14 subscales includes Selfdistraction, active coping, denial, substance use, use of emotional support, use of instrumental support, behavioral disengagement, venting, positive reframing, planning, humor, acceptance, religion, and self-blame. The items of each sub scale are sum up in order to get the total score on 14 sub scales. High score indicate high use of coping and low score indicate low use of this coping strategy.

\section{Procedure}

The procedure started with the approval from the research ethics review committee. After approval, respective hospitals of oncology were approached. Two hospitals agreed to participate in the study. The concerned hospital's ethical considerations were met and approved by the concerned bodies before start of the study. Consent form of voluntary participation was signed by all the participants. A total of 400 questionnaires were distributed and 340 were returned. 40 were discarded because they were incomplete. There was no time limit for the completion of questionnaires.

\section{Ethical Considerations}

The research was endorsed by ethical committees of both university as well as hospitals. All ethical obligations including consent taking, confidentiality, rights to withdraw were explained and signed consent letter was required before data collection. 


\section{Data Analysis}

Statistical analysis based on gender differentiation was executed using SPSS version 22 .

\section{Results}

The present study aimed at exploring gender differences in resilience, coping and quality of life of oncology nurses. Furthermore, the research also looked the impact of coping and resilience on quality of life. The resilience was assessed by using trait and state resilience inventory, coping was assessed by using Brief COPE scale and the quality of life was measured by using World Health Organization Quality of life scale- Brief.

Table 1 provides descriptive information about nurses who participated in the study. Out of a total of 300 nurses, 150 were males and 150 were females. Majority of the nurses were between the ages of 24 to 29 (36.7\%). Nursing qualification had two categories, 90\% were registered nurses and 10\% were unregistered nurses. Professional experience was classified into two categories, 40\% (122 out of 150) of oncology nurses had experience below 5 years whereas 59\% (178 out of 300) had experience above 5 years.

Table: 1

Demographic profile of participants $(n=300)$

\begin{tabular}{|c|c|c|c|}
\hline & Categories & $\mathbf{F}$ & $\%$ \\
\hline \multirow[t]{6}{*}{ Age (Years) } & $18-23$ & 40 & 13.3 \\
\hline & $24-29$ & 110 & 36.7 \\
\hline & $30-36$ & 88 & 29.3 \\
\hline & $37-42$ & 30 & 10.0 \\
\hline & $43-48$ & 12 & 4.0 \\
\hline & $49-54$ & 10 & 6.7 \\
\hline \multirow[t]{2}{*}{ Gender } & Males & 150 & 50.0 \\
\hline & Females & 150 & 50.0 \\
\hline \multirow[t]{2}{*}{ Qualification } & Registered Nurse & 270 & 90.0 \\
\hline & Unregistered Nurse & 30 & 10.0 \\
\hline \multirow[t]{2}{*}{ Professional Experience } & Below 5 years & 122 & 40.7 \\
\hline & Above 5 years & 178 & 59.3 \\
\hline \multirow[t]{2}{*}{ Marital Status } & Married & 196 & 65.3 \\
\hline & Unmarried & 104 & 34.7 \\
\hline
\end{tabular}

\section{Gender Differences in Terms of Resilience in Oncology Nurses}

Firstly, gender differences were examined on scores obtained on Trait and State Resilience Checklist from 300 oncology nurses. Independent sample t test results were statistically non significant. However based on mean differences, it can be concluded that 
males have comparatively more resilience with mean and standard deviation of $(\mathrm{M}=130.80, \mathrm{SD}=17.901)$, whereas females have less resilience with mean and standard deviation of $(\mathrm{M}=119.16, \mathrm{SD}=18.61)$.

Table: 2

Mean (M), standard deviation (SD) and t- score values for state trait resilience checklist $(\mathbf{N}=\mathbf{3 0 0})$

\begin{tabular}{|c|c|c|c|c|c|c|c|c|c|}
\hline \multirow[t]{3}{*}{ Variables } & \multirow{2}{*}{$\begin{array}{c}\text { Males } \\
(n=150)\end{array}$} & & \multirow{2}{*}{$\begin{array}{c}\text { Females } \\
(n=150)\end{array}$} & & & & \multirow{2}{*}{$\begin{array}{c}\mathbf{9 5 \%} \\
\mathrm{CI} \\
\end{array}$} & & \multirow[t]{2}{*}{ Cohen's d } \\
\hline & & & & & & & & & \\
\hline & $\mathrm{M}$ & SD & $\mathrm{M}$ & SD & $\mathrm{t}$ & $\mathrm{P}$ & LL & UL & \\
\hline $\begin{array}{l}\text { Trait and } \\
\text { State } \\
\text { Resilience } \\
\text { Checklist }\end{array}$ & 130.80 & 17.90 & 119.16 & 18.6 & -3.90 & .813 & -17.5 & -5.7 & 0.6 \\
\hline
\end{tabular}

Note. $\mathrm{SD}=$ Standard Deviation, $\mathrm{LL}=$ Lower Limit, UL=Upper Limit.

\section{Gender differences in terms of Coping}

Table 3 compares the gender differences on coping of oncology nurses. The results indicates that males use coping strategies of Self distraction $(\mathrm{M}=7.16, \mathrm{SD}=1.252)(\mathrm{p}=.073$, $\mathrm{t}(-5.77)$,Substance use $(\mathrm{M}=6.12, \mathrm{SD}=2.266) \mathrm{p}=.000, \mathrm{t}(-10.62)$, Behavioral disengagement coping strategy $(\mathrm{M}=5.76, \mathrm{SD}=1.393), \mathrm{p}=.137, \mathrm{t}(-7.02)$, Positive reframing $(\mathrm{M}=7.35$, $\mathrm{SD}=1.020), \quad \mathrm{p}=.013, \mathrm{t}(-5.76)$. Planning $(\mathrm{M}=7.17, \quad \mathrm{SD}=1.094), \mathrm{p}=.026, \mathrm{t}(-5.58)$. Acceptance $(\mathrm{M}=6.96, \mathrm{SD}=1.278), \mathrm{p}=.014, \mathrm{t}(-4.81)$.

Coping strategies used by females are Humor $(\mathrm{M}=5.12, \mathrm{SD}=1.497) \mathrm{p}=.299, \mathrm{t}(.621)$, Active coping $(\mathrm{M}=6.13, \mathrm{SD}=1.388) \mathrm{p}=.073, \mathrm{t}(-5.77)$, Denial $(\mathrm{M}=5.01, \mathrm{SD}=1.581)$, Emotional support $(\mathrm{M}=7.03, \mathrm{SD}=1.479) \mathrm{p}=.156, \mathrm{t}(7.15)$, Instrumental support $(\mathrm{M}=7.11$ $\mathrm{SD}=1.247), \mathrm{p}=.747, \mathrm{t}(6.23)$, Venting $(\mathrm{M}=6.91, \mathrm{SD}=1.654), \mathrm{p}=.501, \mathrm{t}(3.73)$, Religion $(\mathrm{M}=7.56, \mathrm{SD}=.962), \mathrm{p}=.014 \mathrm{t}(3.42)$ Self blame $(\mathrm{M}=6.97, \mathrm{SD}=1.488), \mathrm{p}=.410 \mathrm{t}(7.27)$. This shows that there is an obvious gender differences on coping strategies used by oncology nurses. 
Table: 3

Mean (M), standard deviation (SD) and t- score values for Brief COPE scale and its subscales $(\mathrm{N}=300)$

\begin{tabular}{|l|c|c|c|c|c|c|c|c|c|}
\hline Scale/Subscales & \multicolumn{2}{|c|}{$\begin{array}{c}\text { Males } \\
(\mathbf{1 5 0})\end{array}$} & \multicolumn{2}{c|}{$\begin{array}{c}\text { Females } \\
(\mathbf{1 5 0})\end{array}$} & $\boldsymbol{t}$ & $\boldsymbol{p}$ & \multicolumn{2}{c|}{$\mathbf{9 5 \%}$ CI } & Cohen's D \\
\hline & $\mathbf{M}$ & $\mathbf{S D}$ & $\mathbf{M}$ & $\mathbf{S D}$ & & & $\mathbf{L L}$ & $\mathbf{U L}$ & \\
\hline COPE (Total) & 85.93 & 10.23 & 83.09 & 9.51 & -1.76 & .911 & -6.02 & .348 & 0.28 \\
\hline Self distraction & 7.16 & 1.25 & 5.87 & 1.48 & -5.77 & .073 & -1.73 & -.850 & 0.93 \\
\hline Active coping & 1.247 & 1.24 & 6.13 & 1.38 & $-5.32 \mathrm{a}$ & .082 & -1.57 & -.721 & -3.70 \\
\hline Denial & 4.75 & 1.33 & 5.01 & 1.58 & 1.11 & .156 & -.20 & .739 & -0.17 \\
\hline Substance use & 6.12 & 2.26 & 2.88 & 1.35 & -10.62 & .000 & -3.84 & -2.638 & 1.73 \\
\hline $\begin{array}{l}\text { Emotional } \\
\text { Support }\end{array}$ & 5.16 & 1.70 & 7.03 & 1.47 & 7.15 & .156 & 1.35 & 2.382 & -1.17 \\
\hline $\begin{array}{l}\text { Instrumental } \\
\text { Support }\end{array}$ & 5.76 & 1.39 & 7.11 & 1.24 & 6.23 & .747 & .920 & 1.773 & -1.02 \\
\hline $\begin{array}{l}\text { Behavioral } \\
\text { disengagement }\end{array}$ & 6.43 & 1.69 & 4.61 & 1.46 & -7.02 & .137 & -2.32 & -1.303 & 1.15 \\
\hline Venting & 5.95 & 1.48 & 6.91 & 1.65 & 3.73 & .501 & .452 & 1.468 & -0.61 \\
\hline $\begin{array}{l}\text { Positive } \\
\text { reframing }\end{array}$ & 7.35 & 1.02 & 6.17 & 1.43 & -5.76 & .013 & -1.57 & -.771 & 0.94 \\
\hline Planning & 7.17 & 1.09 & 6.00 & 1.45 & -5.58 & .026 & -1.58 & -.758 & 0.91 \\
\hline Humor & 4.96 & 1.65 & 5.12 & 1.49 & .621 & .299 & -.349 & .669 & -0.10 \\
\hline Acceptance & 6.96 & 1.27 & 5.76 & 1.73 & -4.81 & .014 & -1.69 & -.708 & 0.78 \\
\hline Religion & 6.97 & 1.12 & 7.56 & .962 & 3.42 & .014 & .249 & .925 & -0.56 \\
\hline -Self blame & 5.11 & 1.64 & 6.97 & 1.48 & 7.27 & .410 & 1.36 & 2.374 & -1.18 \\
\hline
\end{tabular}

Note. $\mathrm{M}=$ Mean, $\mathrm{SD}=$ Standard Deviation

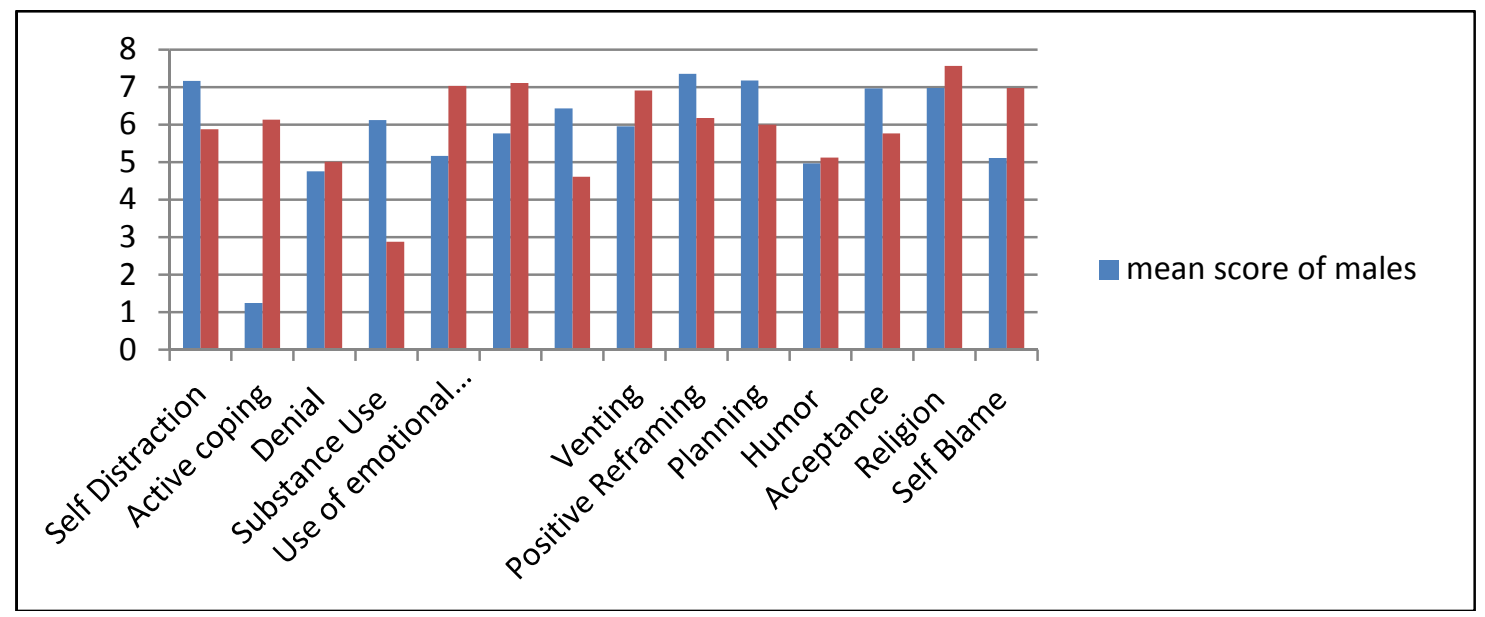

Fig1: Gender Differences in Coping. 


\section{Gender Differences in Terms of Quality of Life}

Table 5 shows gender differences on Quality of life of oncology nurses. The results have shown that quality of life of female is better with mean and standard deviation of $(\mathrm{M}=85.64, \mathrm{SD}=12.224), \mathrm{p}=.000, \mathrm{t}(2.07)$ whereas quality of life of males is slightly less good with mean and standard deviation of $(\mathrm{M}=82.25, \mathrm{SD}=7.085), \mathrm{p}=.000, \mathrm{t}(2.07)$. Physical dimension of quality of life of male and female is almost equal with mean and standard deviation of male is $(\mathrm{M}=23.03, \mathrm{SD}=2.913), \mathrm{p}=.000, \mathrm{t}(.514)$ and mean and standard deviation of female is $(\mathrm{M}=23.35, \mathrm{SD}=4.537), \mathrm{p}=.000, \mathrm{t}(.514)$.Psychological dimension of quality of life of female is better with mean and standard deviation of $(\mathrm{M}=20.52, \mathrm{SD}=3.051), \mathrm{p}=.611, \mathrm{t}(2.84)$ whereas it is slightly less better in males with mean and standard deviation of $(\mathrm{M}=19.13, \mathrm{SD}=2.929), \mathrm{p}=.611$,t(2.84 ). Social dimension of quality of life in both male and female is almost equal with mean and standard deviation for male is $(\mathrm{M}=10.00, \mathrm{SD}=2.144), \mathrm{p}=.021, \mathrm{t}(.611)$ and for female is $(\mathrm{M}=10.24, \mathrm{SD}=2.645) \mathrm{p}=.021, \mathrm{t}(.611)$, Environmental dimension of quality of life of female is better with mean and standard deviation of $(M=25.75, S D=4.981)$, $\mathrm{p}=.078, \mathrm{t}(2.31)$ whereas it is less better in males with mean and standard deviation of $(\mathrm{M}=24.04, \mathrm{SD}=4.001)$.

Table: 5

Mean (M), standard deviation (SD) and t- score values for WHO quality of life scale and its subscales $(\mathbf{N}=\mathbf{3 0 0})$

\begin{tabular}{|l|c|c|c|c|c|c|c|c|c|}
\hline Variables & $\begin{array}{c}\text { Males } \\
(\mathbf{n = 1 5 0})\end{array}$ & $\begin{array}{c}\text { Females } \\
(\mathbf{n = 1 5 0 )}\end{array}$ & & & & $\begin{array}{c}\mathbf{9 5 \%} \\
\text { CI }\end{array}$ & & Cohen's d \\
\hline & $\mathrm{M}$ & $\mathrm{SD}$ & $\mathrm{M}$ & $\mathrm{SD}$ & $t$ & $p$ & $\mathrm{LL}$ & $\mathrm{UL}$ & \\
\hline WHO-QOL & 82.25 & 7.08 & 85.64 & 12.22 & 2.07 & .000 & .163 & 6.611 & -0.33 \\
\hline Physical & 23.03 & 2.91 & 23.35 & 4.53 & .514 & .000 & -.910 & 1.55 & -0.08 \\
\hline Psychological & 19.13 & 2.92 & 20.52 & 3.05 & 2.84 & .611 & .422 & 2.35 & -0.46 \\
\hline Social & 10.00 & 2.14 & 10.24 & 2.64 & .611 & .021 & -.537 & 1.01 & -0.09 \\
\hline Environmental & 24.04 & 4.00 & 25.75 & 4.98 & 2.31 & .078 & .249 & 3.16 & -0.37 \\
\hline
\end{tabular}

Note. $\mathrm{M}=$ Mean, $\mathrm{SD}=$ Standard Deviation, $\mathrm{LL}=$ Lower Limit, UL=Upper Limit, $\mathrm{CI}=$ Confidence interval.

\section{Impact of Resilience and Coping on Quality of Life in Oncology Nurses}

The hierarchal regression analysis was carried out in order to check the impact of coping and resilience on the quality of life of oncology nurses. Quality of life was dependent variable and coping strategies and resilience were independent variables. Table 7 shows that the value of $\mathrm{R}$ square in model 1 is .072 . The value of $\mathrm{R}$ square tells that how much variance in dependent variable is explained by the independent variable. This implies that demographic variables accounts for 7\% variance in Quality of life. The model 1 is 
statistically significant as $F=2.833, \mathrm{p}<0.05$. The value of $\mathrm{R}$ square in model 2 is .191 . The value of $\mathrm{R}$ square tells that how much variance in dependent variable is explained by the independent variable. This implies that coping accounts for $19 \%$ variance in quality of life. The model 2 is statistically significant as $153 \mathrm{~F}=2.83, \mathrm{p}<0.05$. The value of $\mathrm{R}$ square in model 3 is .204. This implies that resilience accounts for $20 \%$ variance in quality of life. The model 3 is statistically significant as $F=1.757, p<0.05$.

Table: 7

Summary of hierarchical regression analysis for variables $(\mathrm{N}=\mathbf{3 0 0})$

\begin{tabular}{|l|c|c|c|c|c|c|c|c|}
\hline & $\mathbf{B}$ & $\mathbf{S E}$ & $\boldsymbol{\beta}$ & $\mathbf{F}$ & $\mathbf{R}$ & $\mathbf{R}^{2}$ & $\mathbf{F}$ & $\mathbf{C h a n g e} \mathbf{R}^{2}$ \\
\hline Model 1 & & & & 2.833 & .269 & .072 & 2.83 & .072 \\
\hline Gender & -3.32 & 1.624 & -.165 & & & & & \\
\hline Age & -.772 & .645 & -.100 & & & & & \\
\hline Marital Status & -2.94 & 2.27 & -.139 & & & & & \\
\hline Experience & 5.69 & 2.25 & .278 & & & & & \\
\hline Model 2 & & & & 2.83 & .438 & .191 & 1.37 & .119 \\
\hline Gender & -2.048 & 3.124 & -.102 & & & & & \\
\hline Age & -.677 & .705 & -.088 & & & & & \\
\hline Marital Status & -3.729 & 2.54 & -.176 & & & & & \\
\hline Experience & 5.971 & 2.32 & .291 & & & & & \\
\hline Self Distraction & -.232 & .913 & -.035 & & & & & \\
\hline active coping & 1.81 & .756 & .258 & & & & & \\
\hline Denial & -.568 & .596 & -.082 & & & & & \\
\hline substance use & -.621 & .476 & -.152 & & & & & \\
\hline $\begin{array}{l}\text { use of emotional } \\
\text { support }\end{array}$ & -.045 & .643 & -.008 & & & & & \\
\hline $\begin{array}{l}\text { use of instrumental } \\
\text { support }\end{array}$ & .922 & .747 & .135 & & & & & \\
\hline $\begin{array}{l}\text { behavioral } \\
\text { disengagement }\end{array}$ & -.318 & .611 & -.318 & & & & & \\
\hline Venting & .986 & .753 & .986 & & & & & \\
\hline positive reframing & 1.92 & .801 & 1.92 & & & & & \\
\hline Planning & -.708 & .778 & -.708 & & & & & \\
\hline Humor & .007 & .590 & .007 & & & & & \\
\hline Acceptance & -.969 & .640 & -.969 & & & & & \\
\hline Religion & -.348 & .882 & -.348 & & & & & \\
\hline Self-blame. & -.571 & .658 & -.571 & & & & & \\
\hline Model 3 & -2.89 & 3.16 & -.144 & & & & & \\
\hline Gender & -.451 & .719 & -.058 & & & & & \\
\hline Age & & & & & & & & \\
\hline
\end{tabular}




\begin{tabular}{|l|c|c|c|c|l|l|l|l|}
\hline Marital Status & -3.81 & 2.53 & -.180 & & & & & \\
\hline Experience & 5.92 & 2.31 & .289 & & & & & \\
\hline Self Distraction & -.312 & .911 & -.047 & & & & & \\
\hline active coping & 1.88 & .754 & .268 & & & & & \\
\hline Denial & -.668 & .597 & -.097 & & & & & \\
\hline substance use & -.649 & .474 & -.159 & & & & & \\
\hline $\begin{array}{l}\text { use of emotional } \\
\text { support }\end{array}$ & -.006 & .641 & -.001 & & & & & \\
\hline $\begin{array}{l}\text { use of instrumental } \\
\text { support }\end{array}$ & .743 & .754 & .109 & & & & & \\
\hline $\begin{array}{l}\text { behavioral } \\
\text { disengagement }\end{array}$ & -.237 & .611 & -.043 & & & & & \\
\hline Venting & .930 & .751 & .151 & & & & & \\
\hline & $\mathbf{B}$ & $\mathbf{S E}$ & $\mathbf{B}$ & $\mathbf{F}$ & $\mathbf{R}$ & $\mathbf{R}$ & $\mathbf{F}$ & Change $\mathbf{R}^{\mathbf{2}}$ \\
\hline positive reframing & 2.137 & .812 & .291 & & & & & \\
\hline Planning & -.957 & .793 & -.134 & & & & & \\
\hline Humor & -.215 & .571 & -.034 & & & & & \\
\hline Acceptance & -1.152 & .656 & -.187 & & & & & \\
\hline Religion & -.501 & .879 & -.054 & & & & & \\
\hline Self-blame. & -.331 & .642 & -.060 & & & & & \\
\hline $\begin{array}{l}\text { State and trait } \\
\text { Resilience }\end{array}$ & .076 & .050 & .143 & & & & & \\
\hline
\end{tabular}

Note. $\beta=$ standardized beta coefficient, $\mathrm{SE}=$ standard error.

\section{Discussion}

The purpose of this research was to assess the gender differences in resilience, coping and quality of life of oncology nurses. The first aim of the study was to look at gender differences in coping of oncology nurses. The results showed that there is a significant gender difference where males used Self distraction, Substance use, Behavioral disengagement, Positive reframing, Planning, Acceptance and instrumental support as a frequently employed coping strategy. These gender differences found are more consistent with the previous findings which predicts that males are socialized to use instrumental coping behaviour while females are socialized to use emotion focused coping behaviour (Pearlin \& Schooler, 1978; Ptacek et al., 1994). Males scored higher in substance use coping strategy. They mostly turned to the use of alcohol and other drugs as a way to disengage them from the stressors. Male nurses mostly use this coping strategy in order to get rid of the stressors which they experienced in their professional lives. In our society it is not socially acceptable for the females to use alcohol or any other drug so they scored less in this coping strategy. Another strategy is planning in which the male nurses scored higher. The reason is that males are mostly involved in thinking about how to 
tackle the stressor and plan about their vital coping efforts and accept the reality of stressors whereas females are involved in denial and they tends to reject the reality of stressful event. Males positively reframe the stressful event by viewing the situation in a more constructive and favourable light. Females usually make joke about the stressful event to distract them from the stress experienced by that event. The humor gives chance for nurses to laugh and play. Females are also involved in seeking instrumental social support by taking guidance about what to do. Religion as a coping strategy is more frequently used by females. They indulge themselves in religious activities like praying, to reduce their stress. In professional life, as oncology nurses have to deal with the death and dying patients on daily basis which produces great anxiety in them. To cope with this situation they pray for the eternal life of a dying patient which results in decrease in their frustrations and anxiety. Results showed that female used Humor, Active coping, Denial, Emotional support, Instrumental support, Venting, Religion and Self blame as frequently employed coping strategies. The results showed that women scored higher than men in emotional support and denial coping styles while scoring lower in substance use and behavioral disengagement coping styles. It is consistent with previous researches where men scored higher in instrumental support and female scored higher in emotional support coping strategy.(Billings \&Moos, 1984; Endler \& Parker, 1990; Folkman \& Lazarus, 1980; Ptacek, Smith, \& Dodge, 1994). Several researchers also reported the similar findings where women use more emotional support coping styles than males in community groups (Billings \& Moos, 1981; Pearlin \& Schooler, 1978). These gender differences found are more consistent with the previous findings which predicts that males are socialized to use instrumental coping behavior while females are socialized to use emotion focused coping behavior (Pearlin \& Schooler, 1978; Ptacek et al., 1992).

The study also looked at gender differences in quality of life in oncology nurses. The results showed that quality of life of female nurses is better as compare to male nurses. Female scored higher in psychological and environmental dimension. In hospitals settings female nurses are given more secure environment and they feel secure and protected within that setting. Female nurses have more opportunities for participation in leisure activities and acquiring more information and skills.

The results showed that the psychological dimension of females is better as compare to males. They are more satisfied with their bodily image and appearance. In psychological dimension of WHOQOL-Bref, there are questions related to self esteem. The female nurses scored higher in self esteem which shows that they have high self esteem. They are more able to concentrate on their work. They do their work with complete devotion and loyalty.

Resiliency is the factor that is more in nurses. Resilient nurse can tolerate the disruptive surroundings and they do not lose their emotional balance. Literature suggests that in 
order to succeed in nursing profession, nurses must have resilience (Jackson, Edenborough \& Firtko, 2007). The results showed that gender difference exists in oncology nurses in terms of resilience. People who come into the nursing profession are usually more resilient than people in general population. The Male nurses are more resilient as compare to female nurses. These findings are consistent with the previous findings (Boardman et al., 2008) which showed that men had higher level of resilience as compare to women. Another research has been given in literature which suggests that boys had greater resilience than girls in adolescence (Deb et al., 2008). This suggests that males are more vulnerable than females towards stress.

One of the objectives was to explore the impact of coping and resilience on the quality of life. Hierarchal multiple regression analysis was employed to find out the contribution of age, gender, professional experience, coping and resilience on the quality of life of oncology nurses. The results showed that resilience had greater impact on quality of life which shows that if the nurses are more resilient then their quality of life will be better and vice versa. Results showed that demographic variables like age, gender, professional experience and marital status of oncology nurses accounts for 7\% variance in Quality of life. Coping accounts for $19 \%$ variance and resilience accounts for $20 \%$ variance in quality of life.

\section{Conclusions}

The results showed that there exists a significant gender difference among these nurses. The results also showed that coping and resilience has an impact on quality of life of these professionals. Resilience still remains under explored in domain of nursing. As body of knowledge grows, interventions based on resilience may be developed to help a nurse spring back from work place adversities and stressors. Gender differences are considerably importance in terms of stress management.

\section{References}

Billings, A. G. \& Moos, R. H. (1981). The Role of Coping Responses and Social Resources in attenuating the Stress of Life Events, Journal of Behavioral Medicine, vol.4:2, pp.139-157.

Billings, A. G. \& Moos, R. H. (1984). Coping, Stress and Social Resources among Adults with Unipolar Depression, Journal of Personality and Social Psychology, vol.46:4, p.877.

Boardman, J. D., Blalock, C. L. \& Button, T. M. (2008). Sex Differences in the Heritability of Resilience. Twin Research and Human Genetics, vol.11:01, pp.12-27. 
Broderick, P. C. \& Korteland, C. (2002). Coping Style and Depression in Early Adolescence: Relationships to Gender, Gender Role, and Implicit Beliefs. Sex Roles, vol.46:7-8, pp.201-213.

Carver, C. S. (1997). You Want to Measure Coping but Your Protocol's too Long: Consider the Brief COPE. International Journal of Behavioral Medicine, vol.4, pp.92-100.

Constantinescu, M. (2012). Using Marketing Research in Quality of Life Theory and Practice. Procedia-Social and Behavioral Sciences, vol.46, pp.754-759.

Deb, U., Hoque, Z., Khaled, N. \& Bairagi, S. K. (2008). Growth, Income Inequality and Poverty Trends in Bangladesh: Implications for Development Strategy. Dialogue on Addressing Regional Inequalities: Policy Options and Strategies, Centre for Policy Dialogue (CPD), Dhaka, February, 28.

Endler, N. S. \& Parker, J. D. (1990). Multidimensional Assessment of Coping: a Critical Evaluation. Journal of Personality and Social Psychology, vol.58:5, p.844.

Folkman, S. \& Lazarus, R. S. (1980). An Analysis of Coping in a Middle-Aged Community Sample. Journal of Health and Social Behavior, pp.219-239.

Frost, J. \& McKelvie, S. (2004). Self-Esteem and Body Satisfaction in Male and Female Elementary School, High School and University Students, Sex Roles, vol.51:1-2, pp.45-54.

Frydenberg, E. \& Lewis, R. (1993). Boys Play Sport and Girls Turn to Others: Age, Gender and Ethnicity as Determinants of Coping. Journal of Adolescence, vol.16:3, p.253.

Gahromi, F. G., Sayehmiri, K. \& Peyman, H. (2013). 571-Gender and Workplace Difference in Coping Strategies among Iranian Nurses, European Psychiatry, vol.28, p.1.

Grant, M., McMullen, C. K., Altschuler, A., Mohler, M. J., Hornbrook, M. C., Herrinton, L. J. \& Krouse, R. S. (2011, September). Gender Differences in Quality of Life among Long-Term Colorectal Cancer Survivors with Ostomies. In Oncology Nursing Forum, vol.38:5, p.587. NIH Public Access.

Hampel, P. \& Petermann, F. (2005). Age and Gender Effects on Coping in Children and Adolescents. Journal of Youth and Adolescence, vol.34:2, pp.73-83. 
Hampel, P. \& Petermann, F. (2006). Perceived Stress, Coping, and Adjustment in Adolescents. Journal of Adolescent Health, vol.38:4, pp.409-415.

Hart, P. L., Brannan, J. D. \& De Chesnay, M. (2014). Resilience in Nurses: An Integrative Review. Journal of Nursing Management, vol.22:6, pp.720-734.

Heyman, G. D. \& Legare, C. H. (2004). Children's Beliefs about Gender Differences in the Academic and Social Domains, Sex Roles, vol.50:3-4, pp.227-239.

Hiew, C. C., Mori, T., Shimizu, M. \& Tominaga, M. (2000). Measurement of Resilience Development: Preliminary Results with a State-Trait Resilience Inventory. Journal of Learning and Curriculum Development, vol.1, pp.111-117.

Isik, A. \& Meriç, M. (2010). Hayatin Kalitesi (Quality of Life) Kavraminin Felsefik Temelleri; Aristo, Bentham Ve Nordenfelt/Quality of Life and it's Philosophical Basis: Aristo, Bentham and Nordenfelt. Ege Akademik Bakis, vol.10:1, p.421.

Jackson, D., Firtko, A. \& Edenborough, M. (2007). Personal Resilience as a Strategy for Surviving and Thriving in the Face of Workplace Adversity: A Literature Review. Journal of Advanced Nursing, vol.60:1, pp.1-9.

Jafari, S., Sadegi, R., Batebi, A., Hosseini, M., Ebrahimpoor, M., Shojaei, F. \& Vaezi, M. (2012). The Effects of Occupational Stress on Quality of Life and Associated Factors among Hospital Nurses in Iran. Journal of Social and Development Sciences, vol.3:6, pp.194-202.

Khan, M. N., Akhter, M. S., Ayub, M., Alam, S. \& Laghari, N. U. (2003). Translation and Validation of Quality of Life Scale, The Brief Version. Journal of the College of Physicians and Surgeons--Pakistan: JCPSP, vol.13:2, pp.98-100.

Lee, M. B. \& Saeed, I. (2001, January). Oppression and Horizontal Violence: The Case of Nurses in Pakistan. In Nursing Forum, vol.36:1, pp.15-24. Blackwell Publishing Ltd.

Luthar, S. S. (2006). Resilience in Development: A Synthesis of Research Across five Decades. In D. Cicchetti \& D. J. Cohen (Eds.), Developmental Psychopathology, Risk, Disorder, and Adaptation 2nd ed., vol.3, pp.739-795, Hoboken, NJ: Wiley.

Meichenbaum, D. (2007). Important Facts about Resilience: A Consideration of Research Findings about Resilience and Implications for Assessment and Treatment. Melissa Institute, Miami, Florida. 
Naylor, M. D. \& Kurtzman, E. T. (2010). The Role of Nurse Practitioners in Reinventing Primary Care. Health Affairs, vol.29:5, pp.893-899.

Pearlin, L. I. \& Schooler, C. (1978). The Structure of Coping. Journal of Health and Social Behavior, pp.2-21.

Pedersen, A. \& Hack, T. F. (2010, January). Pilots of Oncology Health Care: A Concept Analysis of the Patient Navigator Role. In Oncology Nursing Forum, vol.37:1.

Ptacek, J. T., Smith, R. E. \& Dodge, K. L. (1994). Gender Differences in Coping with Stress: When Stressor and Appraisals do not Differ. Personality and Social Psychology Bulletin, vol.20:4, pp.421-430.

Shahzad, A. \& Malik, R. K. (2014). Workplace Violence: An Extensive Issue for Nurses in Pakistan: A Qualitative Investigation. Journal of Interpersonal Violence, 0886260513516005 .

Shakespeare-Finch, J., Gow, K. \& Smith, S. (2005). Personality, Coping and Posttraumatic Growth in Emergency Ambulance Personnel. Traumatology, vol.11:4, p.325.

Dr. Sajida Naz is an Assistant Professor in the Department of Behavioral Sciences, Fatima Jinnah Women University.

Dr. Naima Saeed is an Assistant Professor in the Department of Criminology, University of Karachi.

Dr. Aazadi Fateh Muhammad is an Assistant Professor in the Department of Mass Communication, Federal Urdu University for Arts, Science \& Technology Karachi. 